\title{
The Importance of Dialogue and Tolerance in a Plural Society
}

\author{
Vladimir Bakrac \\ bvladimir@t-com.me
}

\begin{abstract}
This paper is focused on two very important factors when discussing religious pluralism. At first, we would like to remind you than one should distinguish the terms plurality and pluralism and emphasize the importance and significance of dialogue and tolerance in multiconfessional and multicultural societies, therefore in societies with developed religious pluralism, among which Montenegrin society does not fall behind. We start from the belief that it is difficult to speak about religious pluralism in the societies that have no tradition of dialogue and tolerance towards other religions. The paper is intended to be a modest contribution to dialogue and tolerance in the modern world where religion and religious ideas have a very important role. In such a social context, we should not forget that dialogue is the only way to discover the truth, beautiful personality, and a wise thought. Nowadays, dialogue and tolerance are requirements of the time because the world is divided in all possible ways, and yet we must live together and search for what unites us. Neither one social group, just because it is a group, can rely on a unique view of the world. Dialogue and tolerance are powerful barriers to the rule of unilateralism.
\end{abstract}

Keywords: dialogue, tolerance, plurality, pluralism, religion, violence in the name of religion, religious ideology.

\section{Introduction}

From time immemorial, religion besides science, represents a way of explaining the world, it gives meaning to life and universe in which we live. Therefore, it is undeniable sociological function of religion, and on that basis religion today has a very important role in everyday life. Although the majority of the countries have secular system, religion has a very strong influence on many segments of social and political life. Believers, as people who belong to different religions, almost always have quite different explanations for many questions of metaphysical character, although the essence of most religions is the same. Most religions are same or similar in its essence, but they differ in their function, belief and orthopraxy (religious practice, customs, etc. ).

It is enough to remind of a wise principle "do not do to others what you would not want them to do to you", which is incorporated in all religions and their teachings. It is called the principle because it is set opposite the historical experience in order to modify the course of history. All of this is, of course, a challenge for believers. The challenges that believers face are certainly different but I think that priority should be on the dialogue and tolerance, as a kind of prerequisite in the societies with developed religious pluralism. It is difficult to imagine and practically justify a religiously pluralistic society where there is no tolerance towards the other and different beliefs. Also, we are not aware of the fact that there is a society with only one religion and uniform religious conviction. Multiconfessional society, where various religions intersect, where the impact of different religious cultures is felt, where different religious beliefs and religious practice mix, is almost a rule. If environment with uniform or unique religious belief, conviction and action existed, that society would be poor and disabled, because it is not directed to the entire array of other religious beliefs, thoughts and feelings.

The fact is that in these multireligious and multiconfessional societies comes to violence for religion and in the name of religion. None of religion can be amnestied by the fact that they overemphasize its primacy in possession of rights to eternal truth, while they disparage other religions. Why do we emphasize religious ideology and not religion per se? The answer is simple and unambiguous to some extent. If we consider universal dimension of all religions and carefully analyze their catechism, then we must realize that it is completely unnecessary and logically unjustified to talk about violence in the name of religion. The true religion has no contact with that. It is about idolized religion and belief, when that what is universal and transcendent, metaphysical and metalogical is reduced to secular and worldly. We are dealing with religious ideology when religion (church) begins to take an interest in secular things and interests. Now, I think, it is clear why it is necessary to clean religion from ideological residue. When the concept of religion gets in the hands of ideological preferences, then it becomes a weapon for gaining secular interests rather than a tool in spiritual realization. If we closely get to know the dogma of all religions, then we will assure ourselves that values of understanding, cooperation and love, not only towards the members of our own faith but also towards the believers of different faiths, prevail in them. By knowing and 
understanding of what is said, the question "Where do intolerance, hatred and conflicts for faith and in the name of faith come from?" is logically imposed. Bigotry and intolerance do not come from the faith, but from the lack of real and true faith. The answer is, therefore, in religious ideology, when religion is associated with the secular sphere of interest. It is now clear why it comes to interreligious bigotry and intolerance. Believers approach the faith laically, often adopting religious knowledge from the clergy that is quite religiously ideologized and often driven by national and other secular interests.

Christianity is by its nature a peaceful religion that requires unity despite all the differences. All nations are called "to be one", as it is said in the Holy Scripture and "to love their brother as themselves". Jesus said: "This is my commandment, that you love one another as I have loved you" (John 15/12). If someone chooses ideology, he chose not to be a true Christian. Therefore, the logical conclusion is that it is not and it cannot be a conflict between the faiths but it is the conflict between religious ideologies. Religious ideology represents a serious obstacle to tolerance and interreligious dialogue! If the church ties less for its original principles then it becomes more the subject in the service of ideology. It cannot be for and against, but it can be above and beyond any ideology. It is now clear that we cannot talk about the conflict of religions, but about the conflict of ideologies. When the church and church dignitaries involve in ideological core, they drift away from Christianity.

„To represent ecclesiastical disputes and conflicts as disputes and conflicts of faiths, means to hide the truth and conceal the true culprits. The extent to which churches drift away from original faith is the extent to which they have become a source of disputes and conflicts, because they increasingly received characteristics of the world, instead of preserving the characteristic of the sacred" (Šušnjić, 1998, p. 452).

Assuming the ideological outlines and objectives, the church by default creates individuals prone to violence and intolerant individuals who think that they contribute to preservation of their own faith with intolerance and aggressiveness. In fact, it is about the unknown and irrational person, who is not aware that his (mis)deeds are directed by the wishes of religious ideologies and to the detriment of his own original faith. Unfortunately, there are many similar examples, both in the recent and distant history and in the modern world. We will remind of recent example in France since January 2015, when 12 people were killed, at least 10 of them were journalists of a French newspaper (Charlie Hebdo), and the motive was a caricature of the Prophet Muhammad. This is the example where extreme individuals killed for their own faith. Someone will say that they had a "legitimate" reason to commit violence in the name of religion, they felt hurt, and their religion was attacked and threatened, even if it was in the style of offensive caricature. But who can give oneself the right to assume the role of an arbitrator? Is it about a true believer, if he gives himself the right to be God on the earth? We are not sure whether it is a greater sin to make a satirical excess with the Prophet Muhammad, or to take the role which is solely God's providence and role on the earth. The true believer will not kill in the name of religion, no religion considers that favourably. It is well said in the Holy Scripture, "You shall not kill!" Now the question arises, whether an individual who killed in the name of religion is saint or the most terrible sinner? There is no injustice and crime that is committed against faith and that can be redeemed by new injustice and new crime. Trying to take revenge for the injustice done to his own faith, the individual consciously or unconsciously commits a new sin, which cannot be justified by any religion. Assuming God's role of arbitrator on the earth, the believer takes on a new sin towards his own religion. Now we come to ask ourselves whether this is actually about the true believer. Can a believer who commits a crime in the name of his faith, and that faith considers the crime as a sin, be considered a true believer? We think that this is not about the true believer and not about the true religious persons, but rather about the true unbeliever and unreasonable persons who have no idea about their own religion. If it is about the true believer, then he would have to know the dogma and essence of his own faith, and thus he would know that crime does not justify crime. Every crime committed towards a member of another religion, is in fact a crime towards own faith. Not only religions, but also great and profound thinkers talk about non-resistance to evil. Socrates reminds us that it is better to suffer and tolerate injustice than to do it. This wise man begins and ends his life with conversation. For him, thinking is a kind of conversation with himself or with the other and conversation is the same as searching for a man hominem quero. Christ interpreted the thesis "an eye for an eye, a tooth for a tooth" by preaching that we should not defend ourselves from crime, but if someone slaps us on one cheek, we should turn to him the other cheek. Gandhi did not defend himself when they attacked him. 
We will not find any proof that justifies violence, especially the aggressive violence whose terrorism is example par excellence, by adequate access to content analysis of the holy written authorities of any religion of the world. All religions of the world, without exception, essentially reject violence and call for peace or non-violence, as one of the supreme moral principles. Each religious tradition teaches its believers to respect life, especially the life of people, and then the life of other living creatures, and emphasize virtues such as honesty, gratefulness, cooperation, and neo symphony with other people. The word peace is mentioned 155 times in the Hebrew Bible, ninety-six times in the New Testament and we can find in the Koran 140 terms that denote peace, security and tranquillity when translated from Arabic language.

There are religious traditions that absolutize pacifism, such as Sikhism or Jainism, but also there are religions that do not have pacifist ambitions, and when there is a situation where the violence is necessary, what is understandable, but it is still used as a last resort. Actually, this is about violence in self-defence. Therefore, we find the imperative of defence in the Koran, but we shall not find a command that propagates violence which represents a purpose to itself. Also, in the New Testament is said that ". . . everything has its time (. . . ), a time to love and a time to hate; a time of war and a time of peace" (Ecclesiastes 3/8).

In the end, it can be concluded that all religions, without exception, advocate peace and nonviolence, and as such they do not deserve the label of violent or terrorist religion. The committer of that crime is the only one who can be labelled, because peace, love, and tolerance towards all living beings are the basis of every true believer of any religion or confession.

Violence in the name of religion creates a solid base for fundamentalist tendencies, which are by definition angry opponents of the religious pluralism, tolerance towards other religions in multireligious societies, not to speak about science, technology, feminist movements and similar. If we remind of historical memories, even the Balkans cannot be amnestied from similar responsibilities. Nowadays, this region does not have an ear for otherness and differences, the Balkans are unmusical area for accepting the other faiths and cultures and the area where prejudices still have firmly positioned shelter.

\title{
Dialogue and Tolerance
}

\section{(Highlighting the Differences or Finding the Similarities)}

From so far said, I think that we can conclude that highlighting the differences, not similarities, is on the scene. By turning the head from the same or similar, we understand and respect each other less and that is increasingly emphasized in the religious pluralism. Therefore, I will lapidary and compendiously keep on the dialogue and tolerance, which is a key prerequisite to religious pluralistic societies. In such societies, inevitably comes to meeting of the people with different beliefs, whether it is about national, religious or similar beliefs. The differences emerge in the foreground, while the similarities are almost unnoticeable. The sociologist of religion Đuro Šušnjić noted that no matter how much the individuals differ in their opinions, beliefs, nationalities, religion, etc. , they always have something in common, which, in our opinion, represents a good basis for coexistence and cooperation. If a person is aware of this truth, of "this anthropological journey" he is almost aware of his own humanity.

\begin{abstract}
"A man is a man because of his common humanity, not only because of his diversity and uniqueness: common meanings enable understanding, special meanings hinder it. First you have to be a man and then a member of your faith, nation, class, party, etc. Believer and unbeliever, worker and employer, the member of both parties - they all think logically, because logic goes beyond these narrow definitions. Therefore, patriotism is not contrary to the philanthropy. Before each nation there is a nation of people " (Šušnjić, 1997, p. 197).
\end{abstract}

Although every man is different and unique, he also has some characteristics by which he is similar to all the others. Searching for what we have in common with all the others is not just a theory about better understanding, but also it is a practical desire to build the bridges among us which are necessary in this time where bigotry and intolerance have the last word. 
Every religion thinks that it is the only and true carrier of the real truth. All religions believe that there are two truths: theirs and nobody's. The Apostle Paul says: "world has, God knows, how many different voices, but none is without meaning" (Cor. 1.14 to 10). The dialogue is, by definition, a conversation about the common theme among several persons, who, as a rule, have different views, where actors are trying to present and explain their views and then, from that conversation, they modify, enrich and adapt not only their views but also themselves, knowledge, habits and prejudices about others. The aim of the dialogue is not in outsmarting the other; a participant in the dialogue must have a heart that knows how to listen, as Daničić said.

Interreligious dialogue is a special form of conversation. Partners in that dialogue are persons who belong to certain religious traditions and religions in an immediate sense. The basic assumption of religious dialogue is that there are traditional, cultural, historical and confessional boundaries between the participants in the dialogue. It is assumed that each participant has a picture of himself, his religious roots, about what it means to be a representative of the Jewish, Buddhist, Christian or Islamic religion. In the second decade of the $21^{\text {st }}$ century, many people are losing confidence in traditional religious answers that had the canonical value for the generations of their ancestors (Vukomanović, 2001). On the other hand, I think, excessive closeness within traditional borders of their own religions produces another form of danger embodied in unwillingness to dialogue with others and intolerance. All of this leads to religious, racial, national and similar antagonism. This form of communication is often present between some religions.

Willingly or unwillingly, today we have to live in a global, economic, cultural and political environment. In that global communication, meeting people of different religions, nations and cultures is quite normal. That is the truth for which Christ and all the other drivers of the world's religions warn us, but we cannot or do not want to understand and accept that. We can establish interreligious dialogue only if we talk to them, not only about them. A compromise can be reached only if we put other religions and religions different from ourselves on an equal footing - from the standpoint of equal participants. Religion is one of the most original human experiences; therefore, interreligious dialogue is linked with a particular kind of consciousness: participants in the dialogue must be prepared to uncover the roots of their own convictions and beliefs, but also to accept other people's beliefs as equally true, intimate and profound. Partners in the dialogue must be ready to critically approach their doctrinal beliefs. It is necessary to be aware of our own limitations, prejudices and beliefs about the other. Therefore, no one has the right to retain primacy over the possession of whole truth, and the Christian Church should admit that it has no primacy over the possession of the Holy Spirit and that the Holy Spirit is outside the yard of the Christian Church, i. e. everywhere where people live and where they pray. To be tolerant towards someone who believes and thinks differently from us does not mean to be tolerant towards his religion or his God, but towards himself and to accept his faith as equal to ours. There is no place for dialogue and tolerance if everyone sticks to his side of the truth. It is not possible to enter into religious dialogue if each party stubbornly believes that it has primacy over the eternal truth. Ontologically speaking, if we believe that I and You are exactly the same, then it nothing happens to us. Everything that I am not and that is different for me should have a special significance because it is different from me. The result of the dialogue should be the one to complete ourselves by becoming more integrative. Therefore, the essence of the dialogue should be expanding of the Self in connection with others (Šušnjić, 1997). Partners in dialogue must critically approach their doctrines and they must be aware of their own imperfections. Only the one, who knows the essence of all religions, can accept different answers to the same questions and he can clearly and objectively judge his own religion. A true partner in the dialogue is a "man of the third culture" who is deeply aware of advantages and disadvantages of his own culture, as well as advantages and disadvantages of the other culture or tradition in which he lives or which he studies. Today, we are aware of the fact that the truth is increasingly becoming relative and dynamic rather than absolute and static concept. Religious truths are subject to ideological, cultural, linguistic, and similar relativization. Did not the truths set in the Bible and the Koran about position of a woman - to obey and serve husband as Lord and similar, cease to be important in the civilized world a long time ago? These and similar truths should be understood and accepted in the context of time.

In order that interreligious dialogue, which we believe is essential in religious pluralistic societies, should be successful, it must be based on mutual trust. Of course, we should not forget the fact that every religion has fundamental metaphysical, theological and ethical assumptions so the one who represents that religion can be prone to different interpretations of these standards. Our religious principle must not be the point from which we start the dialogue. The Christian cannot enter into dialogue with a Buddhist if he strongly defends the view that there is one God, and he cannot enter into dialogue with the Jew if he strongly defends the view about the Holy Trinity or God-man. I think that we should start the interreligious dialogue with less complicated issues, where there is more than one basis for synthesis and accordance. In the next stage, each of the parties should be introduced with the meaning and values of other religion. During that exchange of symbolic, 
metaphysical, cultural and other values, each of the parties could distinguish a new road and new horizons that they have not been aware of and which could potentially be a guide for a new common journey. I consider dialogue and tolerance not only as a prerequisite to societies with developed religious pluralism, but also as the only way religions should approach one another.

\section{Plurality and Pluralism in the Example of Montenegro}

From the previous discussion we have tried to apodictically prove that, the religion understood and accepted by ideological point of view, is a serious threat to religious pluralism. In societies that are religiously pluralistic, where influences of different faiths and cultures mix, dialogue and tolerance represent a key to mutual coexistence. We will briefly explain the terminological distinctions of the terms plurality and pluralism. Let me remind you that the term pluralism is often used imprecisely not only in laic but also in scientific sphere of interest, especially when it comes to the religious pluralism! I remind you that the religious pluralism includes heritage of Enlightenment and modern liberal democratic state. Therefore, I think that we should point out the difference between plurality as a state of things and pluralism as "an attitude that supports such state of things or idea that normatively justifies it" as Christian Moe names it (Moe, 2004). The main idea of this Islamologist is that we should make difference between theological context of religious pluralism concerning views about the truth, the validity of theological views of other religions on the one hand and the religious pluralism in the social and public sphere on the other hand. It is about relationship between society and politics towards the religious pluralism in the public sphere. Therefore, Moe points out that there are plural societies, in religious sense, in which the religious pluralism does not have major support in the society itself. There are plural societies that do not have problems with theological and social aspects of pluralism, although the state imposes some legal restrictions in the scope of legal regulation. Those restrictions are usually manifested in the terms of registration or division of traditional (historical) and non-traditional religion. Here is the place to explain all of this by the example of Montenegro. The Constitution of Montenegro since 2007 guarantees its citizens the right to freedom of thought and religion, the right to change religion and express their religious beliefs publicly and privately. No one is obliged to declare religion publicly as well as the right to freedom of thought and conscience (Džomić, 2013). Montenegro is a secular state by its regulation. Generally speaking, we can say that Montenegro agreed to some extent its Constitution with Article 9 of the European Convention on Human Rights. However, this Constitution only accepts so-called historical or traditional religions: Metropolitanate of Montenegro and the Littoral, the Montenegrin Orthodox Church, the Roman Catholic Church - Archbishopric of Bar and Bishopric of Kotor and Islamic religious community, all the others have the status of non-traditional religious communities in Montenegro. As far as we know, today in Montenegro, there are more than 20 religious communities. The Montenegrin Roman Catholic Church, which is not recognized by the Holy See in the Vatican, was established recently. In the Constitution of Macedonia, for example, only Macedonian Orthodox Church is legitimized by the Constitution (Article 19), while other churches, for example Serbian Orthodox Church is in a constitutional vacuum. Montenegro is a kind of specificity, because after the dissolution of Socialist Federal Republic of Yugoslavia, religion in all the republics acted in integrative way, examples are Roman Catholic Church in Croatia and Slovenia, as well as Serbian Orthodox Church in Serbia. These churches acted in a very integrative way, protecting identity and national subjectivity in those societies. However, there are two Orthodox churches in Montenegro (Metropolitanate of Montenegro and the Littoral and the Montenegrin Orthodox Church) that cannot be amnestied from disintegrative responsibility in Montenegrin society. The Montenegrin Orthodox Church is presented as a key factor in shaping the Montenegrin national peculiarities, and on the other hand Metropolitanate of Montenegro and the Littoral is presented as only canonically recognized Orthodox church in Montenegro that is trying to marginalize Montenegrin national peculiarity, considering it as a product of communist rule as well as to preserve the unity of Serbian Orthodox Church that was restored in 1920. In all these events, the church acts in a disintegrative way, it often comes out of the bounds of spirituality and tolerance. If we add to this the fact that today in Montenegro there are over twenty religious communities, then we can say that here, in fact, it is about quite religiously diverse area. The Orthodox Church, although it is the most dominant in the number of believers (according to the census of 2011, $72.0 \%$ of the respondents identified themselves as Orthodox), is slowly losing its monopoly. When a religious organization loses its monopoly, then we can talk about a pluralistic society where besides two Orthodox churches we also have the Roman Catholic Church (about 3.5\%) and the Muslim religious community (18. $0 \%$ ). The remaining population consists of members of other religious communities: agnostics, atheists and "undeclared" persons. According to the data of the Ministry of Internal Affairs of 4 November 2013, Montenegro previously reported 19 religious communities with a tendency of further growth. In any case, it is a multiconfessional and multireligious environment, where dialogue and tolerance should have a crucial significance if we 
want to maintain a harmonious community life, despite the differences. We must organize the coexistence guided by the idea that if we cannot live with each other, we can at least live next to each other, of course, respecting all the differences in faith and religious practice.

Montenegro can be proud of the fact that it has a very rich experience of religious tolerance throughout the history. One particularly interesting example is bringing of St. Vladimir's cross in front of the church near Bar, where traditionally Orthodox, Roman Catholic and Muslim believers participate together. It often happens that Orthodox and Roman Catholic Church perform ceremony in the same church. A similar example is in Kotor, a town in the south of Montenegro, where on the day of St. Tripun, Orthodox and Roman Catholic churches and their believers perform ceremony in honour of the mentioned saint. Unfortunately, the burning issue is a conflict between two Orthodox churches, because here, in fact, it is not just about dogmatic issue, but it is also deeply about national and political paradigms.

In the previous part of the text we talked about the great misunderstandings between religions in interreligious and intercultural communication as well as about insufficient knowledge of other and different from ourselves, our own religion and culture. Now we ask ourselves what we actually need to understand. We note that in popular and media discourse, little attention is paid to the basic concepts, not to speak about fundamental distinctions of religious, cultural and political aspects of particular phenomena. In the modern world it is necessary to distinguish global, regional and local varieties. For example, according to the researches of the powerful BBC World Service from 2007, most people in the world consider that the main motives for conflicts are interest and political power but not religion. Therefore, according to the researches of GlobeScan and the University of Maryland from 2006/2007, which included 27 countries and 28,000 respondents, about $56 \%$ of respondents see the common basis between Islam and the West, and only $28 \%$ see the inevitability of the conflict (http: //www. globescan. com/news archives/bbciswest).

There is a number of quite different interpretations and varieties among religions in pluralistic societies. Relationship between religion and politics is not one-sided. If we take the relationship between Islam and Islamism as an example, we will see that Islamism is not as homogeneous as it can be noticed in a superficial analysis. Milan Vukomanović in his book Homo viator makes difference between three aspects of Islamism: a) Islamism as a political and national movement that is aimed at governing the state, establishment of "social justice" or taking the power at democratic elections, but not much more than that; b) missionary Islamism that is aimed at governing the society; c) jihadist Islamism, as a subvariety of the missionary movement, but also the subvariety of the national and political movement (Vukomanović, 2008, p. 74).

The phenomena that marked the religious events in modern world in the late twentieth century were certainly strengthening of Islamism and Islamic revivalism, strengthening of the Christian Right in the USA, as well as the return of classical religiosity in former socialist countries. All these events seriously shook the theories of secularization which were especially popular in the sixties and seventies of the twentieth century and they also intensified the need for glorification and deification of dialogue and tolerance that are essential need for religiously pluralistic societies, as we have tried to prove in this paper. The theory of secularization is not an accidental theory because in that period in the USA and the Western Europe it came to erosion of traditional religiosity and greater openness to new religious movements, and withdrawal of religion from the public into the private sphere, too. One of the most important modern sociologists Peter Berger was a great supporter and an advocate of the theory of secularization in the sixties, but nowadays he completely changed his own theoretical beliefs regarding this issue because empirical evidence indicates desecularization that has tendencies to properly monitor the process of modernization everywhere in the world except in the Western Europe, that is defined as "the exception that proves the rule" by Grace Davie (Davie, 2005, p. 65-83). Because of that, Berger abandoned his previous ideas about the secularization, emphasizing that the assumption that we live in a secularized world is wrong (Berger, 2005, p. 2). The theory that the process of modernization leads to the weakening of religion has no support in the modern theory. The examples in the USA explicitly indicate that. Extremely secular view of the world is still present in countries of the Western Europe as well as within the educated and humanistic elite which in that meaning makes a distinct subculture. Having in mind the above, the religion is no longer possible to ignore, especially if we take into account the consequences that can cause religious beliefs, which we briefly referred to at the beginning of this work. Finally, religious beliefs, that border on fanaticism, indicate that religion and religious beliefs have a very important role in the modern world, especially the consequences they involve and which can be tragic, as we have seen. All these events about revival of religion and religious ideas can be a serious threat to interreligious tolerance in pluralistic societies, especially if we consider the revitalization of religion of the nineties of the twentieth century in almost all parts of the world, most frequently through the New Age, fundamentalist and extremist forms. 


\section{Instead of Conclusion}

We can draw certain conclusions from so far said. In religiously pluralistic societies, where it comes to mixing of different beliefs, dialogue and tolerance should be the starting point. Tolerance is the ability to listen to a man who has different opinion about the same thing, in order to discover contents in his opinion, which could contribute to connection, approach, correction, complement and expression of opinions in a form that would satisfy both sides. We should respect the person who has different opinions, beliefs and religious beliefs even if we are convinced, that what he believes in, seems completely pointless to us.

The extent to which both sides are enriched with knowledge of the religious heritages of other traditions, beliefs and cultures, is the extent to which they could bring out common spiritual paths and realities in the dialogue, which they have not even been aware of before that encounter. Although interconfessional and interreligious encounters are not so often, such a dialogue could become an instrument for new insights and revelations. After such a dialogue, a Christian will feel more like a Christian, a Jew like a Jew, a Muslim like a Muslim, a Buddhists like a Buddhists, etc. All of them would recognize in themselves the ability to become spiritual lighthouses of humanity, the bearers of some fundamental and religious values on which human society lies and survives for thousands of years. In the world, when we can less speak of secularization and more of desecularization and return of religion on the world scene, tolerance should be of crucial importance for coexistence with other faiths and cultures. Especially, we should keep this in mind, if we know the fact that religion returns on the world stage in its quite radical forms that border on fanaticism.

\section{Bibliography}

[1] Berger, P. (2005). The Desecularization of the World: A Global Overview, in: Berger, P. ed. , The Desecularization of the World: Resurgent Religion and World Politics, Grand Rapids. MI. : William Eerdmans.

[2] Davie, G. (2005). Europe: The Exception that Proves the Rule? In. Berger, P. ed. , The Desecularization of the World: Resurgent Religion and World Politics. Grand Rapids, Ml. , William Eerdmans.

[3] Džomić, V. (2013). Church and State in Montenegro. Cetinje, Podgorica, Belgrade. Svetigora - Oktoih.

[4] Moe, C. (2004). Senses of Religious Pluralism: With Particular Reference to Bosniak Islam, www. kotor-netvork. into/articles.

[5] The Old and New Testament of the Holy Bible. (2004). Belgrade. The Holy Synod of the Serbian Orthodox Church.

[6] Šušnjić, Đ. (1997). Dialogue and tolerance. Belgrade. Čigoja Press.

[7] Šušnjić, Đ. (1998). Religion I and II. Belgrade. Čigoja Press.

[8] Vukomanović, M. (2001). The Sacred and the Multitude - Challenges of Religious Pluralism. Belgrade. Čigoja Press.

[9] Vukomanović, M. (2008). Homo viator - religion and new age. Belgrade. Čigoja Press. 74. http: //www. globescan. com/news_archives/bbciswest

\section{BIOGRaPHY}

Vladimir Bakrač was born in Nikšić where he finished primary school. He finished high school in Bar and the Faculty of Philosophy - the Department of Sociology in Nikšić in January 2005. The same year he applied for postgraduate studies at the Faculty of Philosophy in Nikšić - University of Montenegro, where he defended his Master's thesis titled Religion and Nation - Theoretical Analysis of Similarities and Differences in 2008. He applied for doctoral studies at the Faculty of Philosophy - the Department of Sociology in Belgrade in 2009. He defended his doctoral thesis titled Religiosity of the Young in Montenegro at the Faculty of Philosophy in Belgrade in October 2012. Since 2013, he has been engaged in 
teaching at the Faculty of Philosophy in Nikšić (University of Montenegro) as a professor of Sociology of Religion I and Sociology of Religion II.

He is the author of many scientific papers, articles and reviews, mainly in the field of religion, and the participant in a number of national and international scientific conferences. In 2011, 2012 and 2014, he participated in international conferences that were organized by Yugoslav Society for the Scientific Study of Religion - JUNIR, and in 2013 and 2014 he participated in international conferences in Russia, where he published several scientific papers. He participated in conferences that were organized by CANU (Montenegrin Academy of Sciences and Arts) in 2013 and the Faculty of Political Science Podgorica in 2014. The monograph Religion and the Young - Religiosity of the Young in Montenegro was published by National Book and Miba Book. 